\title{
Research on College Student English M-learning Behaviors Based on Mobile Phones
}

\author{
Shuai Hu ${ }^{\text {a,* }}$, Lulu Zhang ${ }^{\mathrm{b}}$ \\ Teaching and Research Institute of Foreign Languages, Bohai University, Keji Street, Jinzhou, China \\ a hushuai6@163.com, b286901864@qq.com \\ * Shuai $\mathrm{Hu}$
}

Keywords: Mobile learning, English, mobile phone

\begin{abstract}
This paper focuses on the characteristics of college student English mobile learning (Mlearning) behaviours by investigating 120 undergraduates. The general condition of their online activities based on mobile phones is first described; then the features of their English M-learning activities are investigated and analyzed. Relationship between their English M-learning behaviours and academic achievements is also studied. At the end, pedagogical suggestions are given concerning students' needs and problems in English M-learning revealed in the study.
\end{abstract}

\section{Introduction}

Information technology is changing people's way of living and learning at an alarming rate and the change will bring education model from a printing era to an information age, which makes education more and more internationalized and personalized. Mobile learning (M-learning) has vastly increased access to information and education opportunities. It breaks the walls of traditional classrooms. [1] Especially in the field of language education, M-learning has gradually become a very important way to learn a foreign language. [2] However, the high-engined development in mobile technology does not promise students' well use of it. Thus this paper tries to picture the current condition of college student M-learning behaviors, especially in the field of English learning.

\section{Development of M-learning Based on Mobile Phones in China}

January 22, 2017, China Internet Network Information Centre (CNNIC) released its 39th statistical report on the development of Internet in China (hereinafter referred to as the report). According to the report, as of December 2016, the number of mobile Internet users in China reached 695 million, accounting for $95.1 \%$ of the total. [3] Just like Evans-Cowley put it: Mobile equipment is increasingly becoming a necessity of daily life. [4] And as for age group among netizens, the proportion of netizens aged 20 to 29 was the highest, with 30.3 percent. Among them, the student group was the largest, with a ratio of $25.0 \%$.

The number of mobile phone online education users was 97.98 million, gaining 44.95 million from the end of 2015 and the growth rate was $84.8 \%$. The usage rate of education users is $14.1 \%$, gaining $5.5 \%$ from the end of 2015 . And among them, the proportion of Internet users using online language training was up to $28.6 \%$.

The above statistics indicate that foreign language M-learning has been gaining popularity at a fast rate in China in the last few years, and the majority of the online learners are college students aged from 19 to 23.

\section{Investigation}

\subsection{Respondents}

In this study, a questionnaire was designed to tentatively probe into student English M-learning behaviours. A total of 120 students of Grade 2016 were surveyed. And they were from College of 
Management and Marine College of Bohai University. To ensure that the students carefully and objectively reveal their own actual situation, before the investigation, students were given unified guidance, informing that the purpose of the survey was to gather information of their online learning, which had nothing to do with their performance evaluation. The two classes from College of Management issued 61 copies of the questionnaire, returning 60 valid responses with a recovery rate of $98.4 \%$. The two classes of the Marine College issued 59 questionnaires, returning 56 valid responses with a recovery rate of $98.4 \%$.

\subsection{Investigation Tool}

The questionnaire consisted of three sections. The first section was about student general online activities based on mobile phones. The second was about their M-learning activities based on mobile phones, and the third was about their M-learning activities in English learning. The subjects responded on a five-point scale from "strongly disagree" to "strongly agree" (1=strongly agree, 2=agree, 3=neutral, 4=disagree, 5=strongly disagree). After the administration of the questionnaire, a statistic check was conducted with each category of items for internal consistency.

\section{Current Condition of College Students' Online Activities via Mobile Phones}

\subsection{Length of Time}

Figure 1 shows the data collected in the questionnaire:

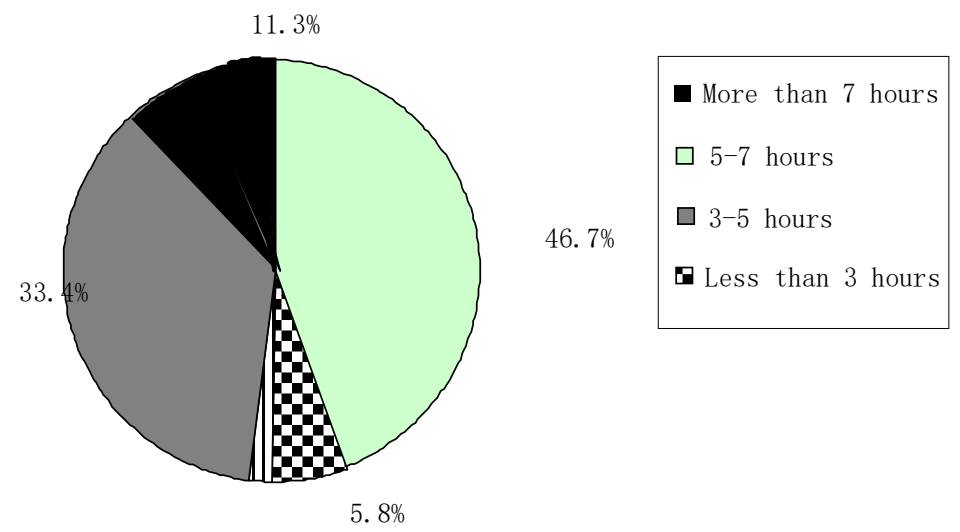

Figure 1 Length of time of online activities.

According to Figure 1, all the students spend some time per day to surf the net using mobile phones. Among them, those who spend less than 3 hours per day account for only $5.8 \%$; those who spend 3-5 hours per day account for 33.4\%; the ratio of students who spend 5-7 hours per day runs up to $46.7 \%$; students who spent even more than 7 hours per day take up $11.3 \%$. According to the investigation, each student spends about 6.5 hours surfing the net with their phones, which takes up the major part of their spare time.

\subsection{Online Activities}

It was found that most students used their mobile phones to surf the Internet mainly for chatting, followed by surfing the web for news. Only $22.6 \%$ students reported that they used their mobile phones to download learning materials for their study everyday. Among all the functions and Apps of mobile phones, the most frequently used Apps were WeChat and QQ. The time spent for academic activities was significantly less than the time spent for entertainment, such as music listening, video watching, mobile games and chatting.

\subsection{Attitude towards M-learning}

As for student attitude towards English M-learning, 79.83\% of the students were very willing to accept M-learning; another $17.64 \%$ were willing to have a try; only $0.25 \%$ percent of students felt 
that M-learning could be a waste of time.

\section{Features of College Student English M-learning Behaviours Based on Mobile Phones}

\subsection{Length of Learning Time}

Among all the students investigated in this research, there were 107 students, accounting for 89.91\%, reported that they had tried learning English online via mobile phone in one way or another. The reason of such high popularity among students is that the most demanded mobile learning content is foreign language learning among all college subjects. [5] And according to the questionnaire result, 54.25\% of them learned English through M-learning for about half an hour per day; $16.82 \%$ of them try to learned English through M-learning for more than one hour per day; 28.93\% spent less than 30 minutes per day.

\subsection{M-learning Content}

In the survey, it is found that most of the students reckoned that it was very convenient to learn vocabulary via mobile phone, which accounts for that fact that most of their English M-leaning activities were centered on vocabulary. 113 students, about $94.96 \%$ of the total number of students, reported that they preferred to learn vocabulary online via mobile phone. The second to it was English listening. 73.1\% reported that they thought it was convenient and productive to do English reading via mobile phone. Besides vocabulary and reading, there were also $46.22 \%$ students did English listening regularly via mobile phone. As to spoken English, it still hadn't been given due attention since students generally focused on exams rather than improve their communication skills.

\subsection{Distribution of M-learning time}

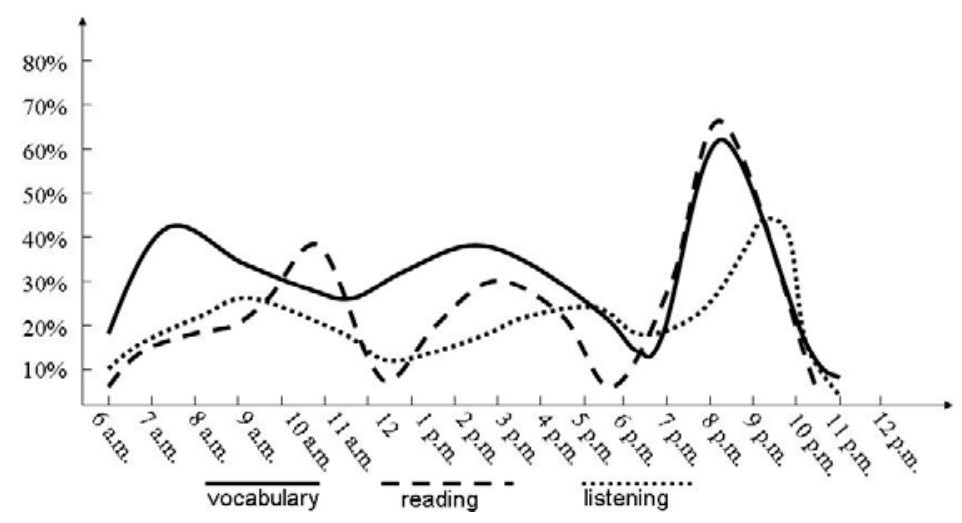

Figure 2 Distribution of English M-learning time.

According to Figure 2, more students learned vocabulary via mobile phones than other English learning activities and the curve of vocabulary learning is comparatively smooth through the day, with a small rise during the night. On the contrary, the curve of reading and listening bounce with time, which means students favored to do these two activities during specific periods of time. Generally, reading and listening were most often practiced between 7p.m. to 10p.m.

\subsection{Other Characteristics of College Student English M-learning Behaviours}

One conspicuous feature of student foreign language M-learning behaviors is that they mainly used fragment time to surf the Internet. 85.24 percent of the students surfed the net using mobile phones during breaks. A lot of students actually reported that they most often learned English via mobile phone for less than 5 minutes.

Another characteristic is that students' M-learning activities are mostly nonsystematic, which means their M-learning activities are usually random, simultaneous and thus often given up half way. Thus it is reasonable to assume that in most cases, students just passively took in the learning content, without in-depth reflection and internalization. 


\subsection{Relationship between Student M-learning Activities and Their Academic Achievements}

To better understand the significance of students' English M-learning activities, the relationship between their behaviors and their academic achievements is also investigated in this research. A Spearman's rho test was done to describe the possible correlation between some variables and students' academic achievements. In this research, students' scores in CET 4 were taken as indicators of their academic achievement. The final result is shown in Table. 1.

Table 1 Relationship between student M-learning behaviours and their academic achievements.

\begin{tabular}{|c|c|c|c|c|c|}
\hline & $\begin{array}{c}\text { Length of } \\
\text { learning time }\end{array}$ & $\begin{array}{c}\text { Learning } \\
\text { consistency }\end{array}$ & $\begin{array}{r}\text { Variety of } \\
\text { learning content }\end{array}$ & $\begin{array}{r}\text { Number of } \\
\text { learning Apps }\end{array}$ & $\begin{array}{c}\text { Learning } \\
\text { attitude }\end{array}$ \\
\hline $\begin{array}{c}\text { Correlation } \\
\text { coefficient }\end{array}$ & $.239^{* *}$ & $.534^{* *}$ & .166 & .073 & $.338^{* *}$ \\
\hline $\begin{array}{c}\text { Sig.(Bilater } \\
\text { al) }\end{array}$ & .007 & .000 & .064 & .419 & .000 \\
\hline
\end{tabular}

From Table 1 we can see that, some factors in M-learning activities do influence student academic achievements. The Sig. values of length of time, consistency and attitude in Table 1 are $.007, .000$ and .000 respectively, which means that the three factors are highly correlated with student academic achievements, while factors like variety of learning content and number of learning Apps are not significantly influential.

\section{Conclusion}

The study indicates that although the majority of college students are trying English M-learning based on mobile phones, they still lack skills and strategies to do it well, and their M-learning activities do influence their English achievements. English is a practical subject, in which improvements can only be achieved by long-term practice in daily life.[6] Learning strategy is one of the main contents of college English teaching. [7] So, college students should be guided with effective learning methods and strategies in their English M-learning practice.

\section{References}

[1] Hu, Sh., (2016) Study on the Training of Foreign Language M-Learning Strategies, Changchun, Jilin People’s Publishing House.

[2] Garrison, D.R. (2011) E-learning in the $21^{\text {st }}$ Century (2nded.), New York, NY: Routledge.

[3] CNNIC. (2017) The 39th Statistical Report on the Development of Internet in China.

[4] The department of higher education of the ministry of education. (2007) Teaching Requirements of College English Courses. Shanghai: Shanghai Foreign Language Education Press.

[5] Cowley, J. E. (2010) Planning in the Real-Time City: The Future of Mobile Technology. Journal of Planning Literature, 25, 136-149.

[6] Lam, P., McNaught, C., Lee, J. and Chan, M. (2014) Disciplinary Difference in Students’ Use of Technology, Experience in Using E-Learning Strategies and Perceptions towards E-Learning. Computers \& Education, 73, 111-120.

[7] Mao Y., Wei, Y. (2013) The Empirical Analysis of University Students Mobile Learning Needs. Library and Information Service, 57, 82-90. 